\title{
STUDI FENOMENOLOGI: MEMAKNAI TATA KELOLA PERUSAHAAN PADA BISNIS KELUARGA BERETNIS TIONGHOA DI INDONESIA
}

\author{
R. A. Widyanti Diah Lestari ${ }^{1)}$ \\ Program Studi Akuntansi, Universitas Internasional Batam \\ widyanti@uib.ac.id
}

\begin{abstract}
Family business in Indonesia has contributed more than half of Gross Domestic Product (GDP). This makes the presence of family businesses, especially ethnic Chinese, an interesting phenomenon to be studied further. There is still a little theory and research that has been done to explore what happens to ethnic Chinese entrepreneurs because they build successful companies and then transfer to the next generation. So this study aims to gain understanding, interpret meaning, and state actions taken by parties involved in family business practices, especially those related to the governance, succession and organizational culture of Chinese ethnicity in Indonesia. The results of the literature study show that the source of strength of ethnic Chinese family businessmen lies in their behavior, where in general the social behavior of ethnic Chinese communities still refers to the beliefs of Confusionism teachings and traditional cultural values of their ancestors. The key to success in doing business with Chinese people is better known as the Guanxi, Ganqing, and Xinyong trilogy, which are the characteristics of human relations in the business world that still need to be explored more deeply whether it is appropriate to apply in Indonesia. In running an ethnic Chinese family business, family members are the main character. To avoid agency conflicts and to perpetuate companies that have been pioneered by its predecessor, in some Chinese ethnic family companies in Indonesia a good governance in family business has been implemented through the distribution of share ownership (there is a percentage of ownership), then also a transparent succession process (starting from the deepest family) with the selection process and the transition stage. The progress of a family company can be demonstrated by increasingly clear rules regarding ownership, management and governance.
\end{abstract}

Keywords: family corporate governance, trilogy (Guanxi, Ganqing, and Xinyong)

\section{ABSTRAK}

Di Indonesia, bisnis keluarga berkontribusi lebih dari setengah dari Produk Domestik Bruto Indonesia (PDB). Hal ini membuat kehadiran bisnis keluarga khususnya yang beretnis Tionghoa menjadi fenomena menarik untuk dikaji lebih lanjut. Masih sedikit teori dan penelitian yang telah dilakukan untuk mengeksplorasi apa yang terjadi pada pengusaha etnis Tionghoa karena mereka membangun perusahaan yang sukses dan kemudian mentransfer ke generasi berikutnya. Sehingga studi ini bertujuan untuk memperoleh pemahaman, menafsirkan makna, dan mengungkapkan tindakan yang dilakukan oleh pihak-pihak yang terlibat dalam praktik bisnis keluarga khususnya terkait dengan tata kelola, suksesi dan budaya organisasi dari etnis Tionghoa di Indonesia. Hasil kajian literatur menunjukkan bahwa sumber kekuatan pelaku bisnis keluarga etnis Tionghoa terletak pada perilakunya, dimana secara umum perilaku sosial masyarakat etnis Tionghoa masih mengacu pada kepercayaan ajaran Konfusionisme dan tata nilai budaya tradisional nenek moyang mereka. Kunci sukses berbisnis pada etnis Tionghoa lebih dikenal dengan istilah trilogi Guanxi, Ganqing, dan Xinyong, yang merupakan suatu karakter hubungan antar manusia dalam dunia bisnis yang masih perlu digali lebih dalam apakah tepat untuk diterapkan di Indonesia. Dalam menjalankan bisnis keluarga etnis Tionghoa, anggota keluarga merupakan pemeran utama. Guna menghindari konflik keagenan dan untuk melanggengkan perusahaan yang telah dirintis oleh generasi pendahulu, pada beberapa perusahaan keluarga beretnis Tionghoa di Indonesia telah dilakukan tata kelola atas perusahaan, yang dapat diketahui dengan adanya pembagian kepemilikan saham (terdapat prosentase kepemilikan), kemudian juga dilakukannya proses suksesi yang transparan (diawali dari keluarga terdalam) dengan adanya proses seleksi dan tahap transisi. Semakin majunya sebuah perusahaan keluarga dapat ditunjukkan dengan semakin jelasnya aturan tentang kepemilikan, manajemen, dan tata kelola.

Kata Kunci : Tata kelola perusahaan keluarga, trilogi (Guanxi, Ganqing, dan Xinyong). 


\section{PENDAHULUAN}

\section{Latar Belakang dan Permasalahan}

Tata kelola perusahaan sering digunakan sebagai solusi untuk menghadapi masalah (konflik) antara perusahaan dan pemangku kepentingan. Untuk menyelesaikan konflik ini, perusahaan biasanya bergantung pada peran pemegang saham mayoritas sebagai pembuat keputusan yang dominan. Di sebagian besar negara, pemegang saham mayoritas adalah anggota keluarga. Meskipun penelitian bisnis tentang bisnis keluarga telah semakin berkembang, namun masih beberapa hal saja yang diteliti dalam suatu studi.Padahal keragaman bisnis keluarga dan tata kelola dan performanya merupakan hal yang cukup menarik untuk dieksplorasi lebih lanjut.

Family business/bisnis keluarga mempunyai peranan penting dalam berkontribusi untuk menghasilkan produk bruto nasional, generasi kerja dan penciptaan kekayaan.Akan tetapi bisnis keluarga juga mempunyai tantangan atas keberlangsungan hidup perusahaan dalam jangka waktu yang panjang.Banyak bisnis keluarga mengalami kesulitan untuk melewati sampai generasi ketiga sehingga beberapa studi lebih berfokus pada suksesi antar generasi (Lam, 2011).Padahal perusahaan yang dimiliki dan dikendalikan oleh keluarga memiliki pengaruh signifikan terhadap organisasi bisnis di dunia (La Porta et al., 1999). Proses tata kelola yang efektif dalam bisnis keluarga memungkinkan penciptaan tujuan yang jelas, menetapkan arah yang tepat dan memotivasi bisnis serta mempertahankan kedisiplinan dalam bisnis dalam pencapaian tujuan bisnisnya.

Pada bisnis keluarga, dimana manajer juga merupakan pemilik bisnis seringkali akan menghadapi tantangan di saat harus menyeimbangkan antara kepentingan keluarga dengan bisnis keluarga, sehingga biasanya terdapat konflik atas kepentingan tersebut. Bisnis keluarga memiliki kemungkinan yang relatif besar untuk mempertimbangkan konflik saat mengambil keputusan, karena keputusan yang diambil akan mempengaruhi kemungkinan pertumbuhan perusahaan dan juga mempengaruhi kemampuannya untuk menciptakan atau mempertahankan tingkat kemakmuran yang diperoleh oleh anggota keluarga, yang bisa memiliki dampak dalam jangka panjang. Sehingga terdapat kebutuhan akan peran tata kelola perusahaan / corporate governance sebagai prinsip utama yang bisa dijadikan acuan untuk mengatasinya. Selain mengidentifikasi prioritas, strategi, sumber daya dan kekuatan untuk membantu menyeimbangkan dua kepentingan yang ada, yaitu untuk mengurangi konflik sehingga kepentingan keluarga dan bisnis bisa berjalan dengan baik (Pounder, 2015).

Konflik pertimbangan dalam pengambilan keputusan tersebut menjadi satu permasalahan utama karena biasanya pemilik bisnis keluarga memiliki visi untuk mampu mewariskan perusahaan yang sehat sehingga memudahkan generasi penerusnya untuk melanjutkan perusahaan tersebut. Visi tersebut bersifat jangka panjang, tetapi dalam proses pencapaiannya seringkali harus menurunkan atau mengorbankan tingkat kesejahteraan 
dari para anggota keluarganya (khususnya istri dan anak) sampai visi tersebut tercapai.

Di sisi lain, apabila pemilik lebih memprioritaskan untuk mempertahankan level kesejahteraan yang saat ini dinikmati oleh para anggota keluarganya, bisnis keluarga bisa mengalami keterbatasan dalam mengembangkan dan mempertahankan kelangsungan hidup perusahaan, karena seringkali kondisi tersebut menciptakan perilaku untuk menghindari beberapa peluang yang sebenarnya lebih menguntungkan tetapi mengandung resiko yang bisa menurunkan tingkat kesejahteraan yang bisa dinikmati oleh keluarganya (Eddleston \& Kellermans, 2007; Molly, Laveren \& Deloof, 2010). Berdasarkan hal tersebut, kemampuan untuk menyeimbangkan kedua jenis orientasi kepentingan yang seringkali bertentangan tersebut harus mampu diwariskan oleh generasi pendahulu kepada generasi penerusnya, demi mempertahankan keunikan yang menjadi keunggulan bersaing utama pada bisnis keluarga. Agar harapan tersebut bisa tercapai, maka harus ada proses perencanaan suksesi yang baik.

Di Indonesia, bisnis keluarga telah menyumbang lebih dari setengah Produk Domestik Bruto Indonesia (PDB). Hal ini membuat kehadiran bisnis keluarga menjadi fenomena menarik untuk dikaji lebih lanjut, seperti yang diungkapkan oleh Suyono (2015), sebanyak 96\% atau 159.000 dari 165.000 perusahaan di Indonesia berdasarkan data dari Biro Pusat Statistik (BPS) merupakan bisnis keluarga yang berkontribusi sebesar $82,44 \%$ dari PDB Indonesia.

Sementara sebanyak 53\% dari perusahaan yang terdaftar di Bursa Efek Indonesia adalah sebuah bisnis keluarga, termasuk perusahaan dari sektor keuangan. Mayoritas bisnis keluarga di Indonesia berkembang dari sebuah perusahaan tradisional. Beberapa pengusaha keluarga terkemuka Indonesia yang menonjol antara lain Lim Sui Liong (Salim Group), Eka Cipta Wijaya (Sinar Mas Group), Mochtar Riady (Lippo Group), dan Chairul Tanjung (Para/CT Group). Keberhasilan bisnis yang mereka rintis dan pertahankan dapat mengangkat derajat sebuah keluarga, namun dinamika yang sering terjadi mengakibatkan konflik yang mungkin dapat memecah belah rasa persaudaraan mereka. Upaya untuk mengelola dinamika bisnis keluarga ke arah yang positif membutuhkan tingkat profesionalisme yang tinggi, atau bahkan rasa persaudaraan yang kuat. Generasi ketiga juga telah mulai mengambil bagian dalam beberapa kelompok bisnis keluarga, seperti misalnya pada Sosro Group, Bakrie, dan Djarum. Perusahaan-perusahaan ini tidak menganut azas keterbukaan dalam praktek perusahaan, sehingga pemegang saham terbesar yang mayoritas anggota keluarga terus mengelola perusahaan seolah-olah perusahaan tersebut masih dimiliki oleh pendiri (Darmadi, 2012).

Perkembangan bisnis keluarga di Indonesia awalnya dari perusahaan-perusahaan tradisional yang mayoritas merupakan bisnis keluarga beretnis Tionghoa. Dalam dunia bisnis, bisnis keluarga di kalangan etnis Tionghola terkenal menjalankan budaya organisasi berdasarkan kebiasaan leluhur mereka yang unik dan sangat menarik perhatian masyarakat, baik di negaranegara barat maupun Indonesia. Banyak etnis/budaya leluhur Tionghoa diterapkan berdasarkan 
nilai-nilai tradisi Konfusian, seperti menjalani kehidupan harmonis dengan menghormati leluhur, keluarga dan relasi, serta penekanan pada pendidikan moral dan integritas seseorang. Selain itu, ada banyak nilai-nilai tradisional yang selalu ditekankan dalam keluarga Tionghoa, seperti hemat, disiplin, kerja keras, dan harga diri (Hsu, 2008).

Karakteristik budaya etnis Tionghoa menurut Kusumastuti, Supatmi dan Sastra (2007), antara lain dengan adanya sistem kekuasaan dan otokrasi (Power and Autocracy), sistem kekeluargaan (Familism), hubungan relasi (Guanxi), harga diri dan kewibawaan (Face and Prestige), serta fleksibelitas dan bertahan hidup (Flexibility and Endurance). Bedasarkan karakteristik inilah kemudian etnis Tionghoa seringkali dianggap memiliki pengaruh yang kuat terhadap dunia bisnis di Indonesia bahkan di Asia.Memahami budaya sebagai dasar untuk pengambilan keputusan di bisnis keluarga membutuhkan nilai dan peran yang besar. Karakteristik seperti agresivitas, keberanian, dan persaingan antara pemilik bisnis keluarga dan anggota keluarga lainnya merupakan bagian alami dari konstruksi pemahaman tata kelola perusahaan dan pengambilan keputusan dalam bisnis keluarga (Pounder, 2015).

Dengan demikian bisnis keluarga beretnis Tionghoa adalah topik yang sangat menarik untuk dikaji. Hasil studi tentang bisnis keluarga di Indonesia dengan kualitas tata kelola perusahaan, suksesi dan budaya organisasi etnis Tionghoa yang dikaji secara kualitatif interpretif masih kurang. Kebanyakan peneliti lebih berfokus hanya pada mekanisme tata kelola perusahaan (secara kuantitatif). Masih sedikit teori dan penelitian yang telah dilakukan untuk mengeksplorasi apa yang terjadi pada pengusaha beretnis Tionghoa setelah mereka membangun perusahaan yang sukses dan kemudian harus mengalihkan ke generasi berikutnya. Oleh karena kebaruan studi ini akan berfokus pada pemahaman, penafsiran makna dan tindakan dari perencanaan suksesi yang dilakukan oleh pihak-pihak yang terlibat dalam praktik bisnis keluarga terkait dengan tata kelola perusahaan dan budaya organisasi dari etnis Tionghoa di Indonesia.

\section{Permasalahan Studi}

Bisnis keluarga biasanya dimulai dari perusahaan berskala kecil dan beroperasi secara lokal. Seiring waktu, beberapa bisnis keluarga berkembang menjadi sebuah perusahaan multinasional yang kuat dan berhasil bersaing dengan perusahaan publik terkemuka di dunia. Sebagai bisnis milik keluarga yang mengalami transformasi ini, melalui proses suksesi, fokus bisnis keluarga akan bergeser dari kelangsungan hidup jangka pendek menjadi lebih luas dengan adanya diversifikasi, profesionalisasi dan internasionalisasi. Evolusi ini sering disertai dengan perubahan besar dalam strategi dan tata kelola perusahaan. Bisnis keluarga mendukung keberhasilan dalam peningkatan perekonomian sebagian besar negara di seluruh dunia. Bisnis keluarga memiliki tantangan atas keberlangsungan hidup perusahaan dalam jangka waktu yang panjang yaitu mengenai perencanaan suksesi. Banyak bisnis keluarga mengalami kesulitan kesulitan untuk lolos sampai generasi ketiga. 


\begin{abstract}
Masalah umum yang paling banyak dihadapi dalam bisnis keluarga adalah terkait suksesi. Hal ini sesuai dengan teori yang sering muncul dalam isu suksesi bisnis keluarga, seperti perencanaan suksesi yang tidak jelas dan konflik antara calon pengganti. Perencanaan suksesi akan menjadi lebih kompleks ketika pemilik usaha memiliki lebih dari satu anak. Dalam menjalankan perusahaan, akan ada kemungkinan timbulnya perbedaan pendapat, dan perbedaan metode yang digunakan dalam menjalankan manajemen perusahaan masing-masing anak yang menjadi penerus bisnis keluarga tersebut. Suksesi akan berhasil jika proses suksesi yang direncanakan sejak awal telah melibatkan suksesor pada pengelolaan bisnis sejak awal, dan dilakukan berbagai pelatihan, serta menciptakan sistem penghargaan yang mendorong calon penggantinya untuk menggantikan peran pendahulunya dengan baik (Susanto \& Susanto, 2013).
\end{abstract}

\section{Tujuan dan Manfaat Studi}

Studi ini bertujuan untuk memperoleh pemahaman, menafsirkan makna dan tindakan yang dilakukan oleh pihak-pihak yang terlibat dalam praktek suksesi terkait dengan tata kelola bisnis keluarga beretnis Tionghoa di Indonesia dalam rangka melanggengkan perusahaan mereka.

Urgensi dari studi ini adalah agar dapat memberikan kontribusi terhadap tata kelola dan kebijakan yang akan diambil dalam praktek suksesi bisnis keluarga beretnis Tionghoa di Indonesia kepada generasi berikutnya. Dengan demikian studi ini dapat digunakan sebagai acuan bagi pengusaha lain yang juga harus mewariskan usahanya kepada pewarisnya.

\section{Justifikasi Studi}

Bisnis keluarga perlu menunjukkan visi perusahaan dan harus mempekerjakan profesional untuk membantu dalam mengintegrasikan sistem dan prosedur yang tepat ke dalam perusahaan. Selain itu, manajemen harus disiplin dan selalu berkomunikasi dengan anggota keluarga, memiliki rencana suksesi yang jelas dan memiliki distribusi kepemilikan saham. Ada banyak faktor yang menyebabkan kegagalan suksesi. Beberapa pemilik menolak rencana suksesi karena mereka merasa terancam, takut kehilangan kekuasaan, keinginan mereka untuk menghindari perlakuan istimewa anak-anak, atau karena takut kehilangan identitas di perusahaan yang telah mentenarkan namanya di masyarakat. Namun, karena pengaruh usia yang terus berlanjut menyebabkan pengusaha harus melakukan perencanaan suksesi untuk kelangsungan hidup perusahaan.

Seperti perusahaan pada umumnya, bisnis keluarga juga memiliki kultur / budaya organisasi. Budaya organisasi ini ditentukan oleh tiga komponen yang dirumuskan oleh Dyer (2010) meliputi keluarga (family), bisnis (business) dan tata kelola perusahaan (Corporate Governance). Awalnya, bisnis keluarga umumnya memiliki budaya yang terbentuk dari pola bisnis yang paternalistik, pola keluarga patriarkal dan pola tata kelola perusahaan yang didasarkan pada rubber-stamp dewan direksi. Artinya, hubungan keluarga lebih penting daripada keterampilan profesional, pendiri adalah pemimpin yang dominan dan memiliki kekuasaan untuk menentukan siapa 
yang tidak tergoyahkan, dan dewan direksi secara otomatis akan mendukung setiap keputusan pendiri perusahaan. Seiring waktu, proses transisi kepemimpinan di perusahaan pun tak terelakkan lagi. Entah transfer kepada generasi keluarga berikutnya maupun ke pihak profesional. Hal ini pastinya akan merubah konfigurasi budaya yang semula dianut. Biasanya sang suksesor akan berusaha untuk mengurangi porsi dominan sang pendiri, walaupun belum tentu berhasil. Dalam proses tersebut, konfigurasi budaya yang semula melekat erat pada perusahaan mungkin tidak efektif lagi.

Tata kelola perusahaan memiliki prinsip TARIF (Transparansi, Akuntabilitas, Tanggung Jawab, Independensi dan Fairness), yang berfungsi sebagai panduan bagi perusahaan. Prinsipprinsip tersebut harus diimplementasikan dalam setiap aspek dalam perusahaan bila ingin menjalankan tata kelola perusahaan dengan baik.Namun penerapan prinsip-prinsip tersebut memiliki berbagai macam kendala khususnya bila diterapkan pada bisnis keluarga.Dalam menjalankan bisnis keluarga, idealnya ada keseimbangan antara bisnis dan keluarga.Kenyataannya sering terjadi pengambilan keputusan lebih mengutamakan kepentingan keluarga dibandingkan dengan bisnisnya.Akibatnya, bisnis keluarga cenderung konservatif dan resisten terhadap perubahan. Padahal dunia bisnis selalu menginginkan perubahan dari waktu ke waktu sesuai dengan perubahan zaman agar perusahaan bisa lebih kompetitif (Susanto, 2009).
KAJIAN LITERATUR Family Business / Bisnis Keluarga

Sebuah perusahaan bisa diklasifikasikan sebagai bisnis keluarga, ketika perusahaan tersebut didirikan oleh dua atau lebih anggota keluarga yang akan selalu melakukan pengawasan terhadap kinerja keuangan perusahaan. Suatu organisasi juga akan diklasifikasikan sebagai bisnis keluarga, ketika setidaknya ada dua (2) generasi dari keluarga yang terlibat dalam perusahaan dan memiliki pengaruh besar terhadap pengambilan keputusan perusahaan (Ward, 1997).

Bagaimanapun, terdapat banyak definisi yang berbeda dari bisnis keluarga dalam literatur. Antara lain, Morck dan Yeung (2004) yang berpendapat bahwa bisnis keluarga memiliki dua kriteria, yaitu (1) pemegang saham terbesar dari perusahaan adalah keluarga tertentu, dan (2) proporsi kepemilikan keluarga lebih besar dari $10 \%$ atau $20 \%$ dari saham dengan hak suara. Studi tentang kinerja dari bisnis keluarga dan non-bisnis keluarga juga telah dibahas hampir di seluruh dunia (Anderson \& Reeb, 2003; Amran \&Ahmad, 2010).Kepemilikan keluarga adalah lazim dan menempati posisi sepertiga dari perusahaan yang terdaftar dalam S \& P 500 dan menyumbang $18 \%$ dari saham perusahaan.Hasil ini konsisten dengan temuan Mc.Conaughy, Walker, Henderson, dan Mishra (1998).

Kinerja perusahaan dalam studi sebelumnya dapat ditinjau berdasarkan nilai perusahaan. Hasil studi menunjukkan bahwa tata kelola mempengaruhi nilai perusahaan sebagai akibat dari berkurangnya pengambilalihan oleh orang dalam dan peningkatan arus kas yang diharapkan yang dapat didistribusikan 
kepada investor (Gomper, Ishii \& Metrick, 2003).

Terdapat beberapa tahapan dalam pengembangan bisnis keluarga, Kodrat (2008) telah mengadopsi model lima tahap bisnis keluarga dari
Susanto (2005) yang terdiri dari tahapan existence / keberadaan, survival / kelangsungan hidup, success / kesuksesan, renewal / pembaharuan, dan rejuvenate/decline (peremajaan/penurunan).

Gambar 1

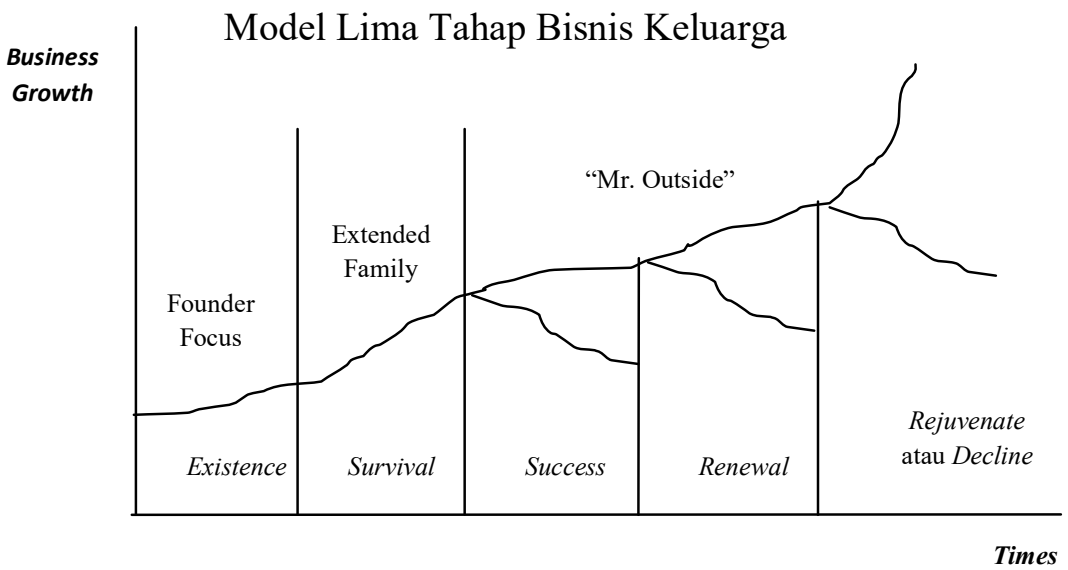

Sumber :Susanto (2005) in Kodrat (2008)

Model perkembangan bisnis keluarga tersebut dapat digunakan sebagai pedoman dan petunjuk kapan sebaiknya pendiri perusahaan mempersiapkan diri untuk memilih, mendidik dan menyerahkan kelanjutan tanggungjawab bisnis keluarga yang dipegangnya selama ini kepada generasi penerusnya, dan apa saja tantangan yang kemungkinan akan dihadapi oleh generasi penerus bisnis keluarga tersebut. Fase kritis biasanya terjadi saat dilakukannya proses suksesi, sehingga biasanya akan mempengaruhi prospek keberlanjutan bisnis keluarga yang akan menjadi "muda" kembali atau justru mengalami penurunan dan kemudian kehancuran. Dengan demikian, proses suksesi merupakan tahapan yang harus dilalui oleh bisnis keluarga, sehingga harus direncanakan dengan baik dan sistematis demi keberlanjutan bisnis keluarga di masa mendatang baik jangka pendek maupun jangka panjang.

\section{Teori Tata Kelola Perusahaan}

Pucuk pimpinan manajemen pada sebuah perusahaan publik biasanya bukanlah pemilik perusahaan. Tetapi kenyataannya, sebagian besar manajer puncak saat ini hanya memiliki sebagian kecil dari saham di perusahaan yang mereka kelola. Para pemilik sebenarnya (pemegang saham) memilih dewan direksi yang mempekerjakan manajer sebagai agen mereka untuk menjalankan kegiatan perusahaan sehari-hari. Setelah dipekerjakan, pertanyaan seperti : Apakah dan bagaimana manajer puncak ini dapat dipercaya dalam mengelola perusahaan? atau Apakah pihak manajemen yang telah ditunjuk sebagai pengelola perusahaan bisnis ini akan lebih mementingkan diri mereka sendiri atau untuk 
kepentingan perusahaan? menjadi seringkali dipertanyakan (Wheelen \& Hunger, 2004). Ada beberapa teori yang dikembangkan untuk menjawab pertanyaan-pertanyaan ini, yang umumnya didasarkan pada teori keagenan.

\section{Teori Keagenan (Agency}

\section{Theory)}

Sebagian besar studi tentang tata kelola perusahaan berasal dari teori keagenan.

$\begin{array}{lc}\text { a. Teori } & \text { keagenan } \\ \text { menggambarkan } & \text { organisasi }\end{array}$ sebagai adanya hubungan kontrak antara pelaku kepentingan pribadi dan agen, termasuk manajer, pemegang saham dan dewan direksi, dan berpendapat bahwa yang bertahan adalah mereka yang terbaik ketika dapat memecahkan permasalahan dalam hal meminimalkan biaya agensi (Eisenhardt, 1989).

b. Teori keagenan adalah teori kepemilikan (atau modal) struktur perusahaan (Jensen \& Meckling, 1976).

c. Ide utamanya adalah bahwa hubungan prinsipal-agen harus mencerminkan organisasi yang efisien, dan terkait dengan risiko atas biaya (Eisenhardt, 1989).

d. Teori keagenan berbeda dari Ekonomi Biaya Transaksi dalam penekanan intraorganisasi terhadap sikap risiko prinsipal dan agen (Eisenhardt, 1989).

Dari perspektif bisnis keluarga, beberapa konflik dan tantangan yang biasanya timbul sebagaimana yang dialami dalam perusahaan non-keluarga adalah bagaimana menyelaraskan kepentingan antara manajer dan pemilik. Hal ini mengingat bahwa pada bisnis keluarga biasanya manajer dan pemilik adalah orang yang sama. Di mana hal ini tidak selalu dapat meningkatkan efektivitas pengambilan keputusan, hanya mempercepat efisiensi (Jensen \& Meckling, 1976; Anderson \& Reeb, 2003; Pounder, 2015).

Studi yang dilakukan Jensen dan Meckling (1976), menggambarkan bahwa perusahaan bukanlah individu tetapi sebuah badan hukum, di mana terdapat tujuan yang saling bertentangan antar individu yang dibawa ke dalam kerangka hubungan kontrak. Hubungan kontrak ini tidak hanya terjadi dengan karyawan, tetapi juga dengan pemasok, pelanggan dan kreditur. Tujuan dari kontrak ini adalah bahwa semua pihak akan bertindak untuk kepentingan mereka sendiri dengan tujuan untuk memaksimalkan nilai organisasi, mengurangi biaya agensi dan menerapkan metode akuntansi yang efisien agar dapat mencerminkan kinerja mereka sendiri (Deegan, 2004).

\section{Teori Stewardship}

keagenan,

Berbeda dengan teori Stewardship/pengelolaanmerupakan bentuk yang berbeda dari sisi manajemen, di mana manajer dianggap sebagai manajer yang baik dan akan bertindak untuk kepentingan pemilik (Donaldson \& Davis, 1991). Dasar-dasar teori pengelolaan ini berdasarkan psikologi sosial, yang berfokus pada perilaku eksekutif. Perilaku Steward adalah pro- 
organisasi dan kolektif, dan memiliki nilai kegunaan yang tinggi bagi perusahaan, sementara perilaku manajer tidak akan dimulai dari kepentingan organisasi, karena manajer akan berusaha untuk mencapai tujuan organisasi. Ketika posisi CEO dan Chairman dipegang oleh satu orang, nasib organisasi dan kekuatan untuk menentukan strategi merupakan tanggung jawab satu orang, sehingga teori Stewardship memiliki pandangan lain yaitu adanya pemisahan peran dari CEO dan Chairman, karena teori ini melihat hubungan yang kuat antara manajer dan kesuksesan perusahaan. Oleh karena itu manajer akan melindungi dan memaksimalkan nilai pemegang saham melalui kinerja perusahaan. Seorang manajer yang berhasil akan meningkatkan kinerja, dan memenuhi sebagian besar harapan kelompok pemangku kepentingan dalam sebuah organisasi untuk meningkatkan kekayaan organisasi (Davis, Schoorman \& Donaldson, 1997).

\section{Tata Kelola Perusahaan}

Corporate governance menurut Turnbull Report di Inggris seperti yang dijelaskan oleh Effendy (2009) merupakan sistem pengendalian internal perusahaan, yang tujuan utamanya untuk mengelola risiko yang signifikan terhadap pemenuhan tujuan usahanya, dengan maksud untuk menjaga aset perusahaan dan meningkatkan nilai investasi pemegang saham dari waktu ke waktu. Berdasarkan Pasal 1 SK Menteri BUMN No. 117/MMBU/2002, menyatakan bahwa tata kelola perusahaan adalah suatu struktur dan proses yang dapat digunakan untuk mengembangkan keberhasilan usaha dan akuntabilitas perusahaan guna meningkatkan nilai pemegang saham tanpa merugikan para pemangku kepentingan lainnya.

Carter, Simkins dan Simpson (2003) menyatakan bahwa salah satu isu penting dalam tata kelola yang dihadapi manajer, direktur dan pemegang saham dalam perusahaan modern adalah komposisi gender, ras, dan budaya dewan.Isu ini menjadi perhatian publik sebagai akibat dari pemberitaan di media, permintaan pemegang saham, dan persyaratan yang diajukan oleh investor institusional besar.Hal ini karena adanya tata kelola perusahaan dapat mendorong terbentuknya pola kerja manajemen yang bersih, transparan, dan profesional. Pelaksanaan prinsipprinsip tata kelola perusahaan secara konsisten akan menarik investor, sehingga sangat penting bagi perusahaan yang ingin mengembangkan usahanya (investasi baru dan proyek ekspansi).

Terdapat banyak dimensi yang berhubungan dengan meningkatnya minat terhadap pemahaman tentang tata kelola perusahaan. Bagi pengatur kebijakan dan pelaku praktek bisnis, tata kelola perusahaan saat ini telah diterima secara luas sebagai disiplin penting yang harus dipahami dan dilaksanakan oleh manajer untuk mencapai akuntabilitas dan kinerja. Dari sisi hukum bisnis, isu-isu tata kelola perusahaan menjadi semakin menonjol, dimana tugas dan tanggung jawab seorang manajer seringkali dipertanyakan. Bagi pemerintah, tata kelola perusahaan yang baik saat ini menjadi hal penting karena berguna untuk meningkatkan integritas dan efisiensi pasar, dan sebagai dasar stabilitas keuangan dan pertumbuhan ekonomi (Clarke \& Branson, 2012).

Satu hal yang menjadi isu utama dalam reformasi ekonomi Indonesia setelah berakhirnya krisis 
1997-1998 adalah tentang tata kelola perusahaan. Subjek tata kelola perusahaan adalah isu yang berkembang di negara-negara Asia, dan Indonesia tidak terkecuali (Sato, 2003). Masalah keagenan yang terjadi dalam tata kelola perusahaan, tidak hanya terjadi antara pemegang saham dengan pihak manajemen, tetapi juga dapat terjadi antara pemegang saham mayoritas dan manajemen dengan pemegang saham minoritas (Villalonga \& Amit, 2006).

Perusahaan yang didominasi oleh kepemilikan keluarga dapat dijalankan dengan lebih efisien karena biaya monitoring yang lebih kecil. Pengendalian atas biaya menjadi lebih kecil karena kepemilikan yang terkonsentrasi, sehingga lebih sedikit konflik yang terjadi dibandingkan perusahaan dengan kepemilikan tersebar. Selain itu, perusahaan dengan kepemilikan keluarga yang dominan dijalankan oleh para anggota keluarganya sendiri sehingga lebih dapat dipercaya, sehingga konflik keagenan menjadi berkurang (Fama \& Jensen, 1983). Di sisi lain, masalah keagenan yang timbul tidak lagi antara pemilik dan manajemen, tetapi terjadi antara pemegang saham minoritas dengan keluarga pemilik, termasuk dengan pihak manajemen yang berasal dari keluarga. Pemegang saham mayoritas, dalam hal ini keluarga, memiliki kecenderungan untuk mempertahankan dominasinya di perusahaan, melalui manajemen dan juga pembatasan praktik tata kelola perusahaan yang baik (Classens et al., 2002). Siagian (2011) dalam studinya secara empiris di Indonesia membuktikan bahwa tingkat kepemilikan keluarga memiliki efek negatif terhadap pelaksanaan tata kelola perusahaan karena dengan menghindari tata kelola akan cenderung mengurangi kontrol dari pemegang saham pengendali.

Mekanisme tata kelola perusahaan adalah salah satu cara untuk melindungi kepentingan pemegang saham minoritas. Keluarga sebagai pemegang saham mayoritas akan mempertahankan kontrolnya untuk terus mendapatkan keuntungan dari pemegang saham minoritas. Penerapan tata kelola perusahaan dengan proporsi kepemilikan keluarga yang tinggi tidak akan berjalan dengan baik (Haque, Arun, \& Kirkpatrick, 2011).

\section{Suksesi pada Bisnis Keluarga}

Suksesi adalah keseluruhan proses bisnis untuk mempersiapkan pengalihan kekuasaan dan kontrol dari generasi ke generasi (Aronoff, 1998). Survei yang telah dilakukan oleh Lansberg (1999) menunjukkan rendahnya "survival rate" pada bisnis keluarga. Hasil survei menunjukkan hanya $30 \%$ bisnis keluarga di seluruh dunia yang mampu bertahan sampai pada generasi kedua. Sehingga dapat diartikan bahwa $70 \%$ bisnis keluarga telah gagal untuk meraih sukses di tangan generasi kedua. Yang menjadi salah satu faktor utama rendahnya survival rate ini terletak pada lemahnya perencanaan suksesi.

Terdapat banyak faktor yang menyebabkan terjadinya keruntuhan akibat dilakukannya suksesi dalam bisnis keluarga. Biasanya beberapa pemilik perusahaan (generasi terdahulu) menolak rencana suksesi karena mereka merasa terancam, takut kehilangan kekuasaan, menghindari perlakuan istimewa dari anak-anak mereka, atau karena hilangnya identitas di sebuah perusahaan yang telah membuat terkenal namanya dalam dunia bisnis 
di masyarakat. Namun, karena pengaruh usia yang telah lanjut menyebabkan pengusaha tersebut harus melakukan perencanaan suksesi untuk kelangsungan hidup perusahaan (Harveston, Davis \& Lyden, 1997).

Soedibyo (2007) menuturkan bahwa membangun bisnis keluarga tak ubahnya mengarungi kehidupan.Perusahaan dibangun untuk terus tumbuh dan dipelihara agar terus dapat berkembang.Namun, seperti halnya kehidupan, tidak semua perusahaan mampu hidup dan bertahan dalam jangka waktu yang lama atau bertahan dari generasi ke generasi dan mencapai cita-cita pendiri.Ada banyak faktor yang dapat menentukan keberhasilan perusahaan untuk bisa bertahan dari waktu ke waktu.Hal itu tentunya juga berlaku bagi bisnis keluarga yang dibangun dan dikelola oleh anggota keluarga untuk dapat bertahan selama mungkin.Salah satu kunci keberhasilan bisnis keluarga untuk bertahan dalam jangka waktu panjang adalah dengan adanya suksesi kepemimpinan.

Morris, William dan Nel (1996) menemukan tiga kelompok atribut yang mempengaruhi bisnis keluarga, antara lain : (1) kegiatan perencanaan dan pengendalian, (2) hubungan keluarga, dan (3) persiapan untuk setiap jenjang penerus. Oleh karena itu, untuk mendukung keberhasilan dalam setiap tahap transisi, mereka harus mempersiapkan penerus dengan baik, membangun hubungan keluarga, dan memastikan semua perencanaan dan pengawasan informal kegiatan yang dapat menciptakan kesuksesan.Pengaruh yang paling signifikan dalam transisi hubungan keluarga adalah komunikasi dan kepercayaan.Bisnis keluarga adalah sebuah organisasi yang membiarkan anggota keluarga mengontrol dan mengelola perusahaan mereka untuk mencapai visi perusahaan dan membuat perencanaan untuk meneruskannya hingga ke generasi berikutnya.Implikasi rencana suksesi dalam bisnis keluarga melibatkan beberapa pihak.Pihak-pihak terkait termasuk anggota keluarga yang bekerja di perusahaan maupun di luar perusahaan, karyawan dari hubungan bukan keluarga, pendiri, pemasok, dan pelanggan.

Sebagaimana dinyatakan oleh Lam (2011), hingga saat ini beberapa penelitian hanya berfokus pada bisnis keluarga terkait dengan proses suksesi, tetapi sangat sedikit yang mencoba untuk memahaminya secara interaktif, sebagai proses sosial yang dinamis, dan kebanyakan peneliti lebih memilih untuk mencurahkan lebih banyak usahanya untuk menjelaskan masalah daripada bagaimana memecahkan hal itu. Itulah mengapa, seperti yang disarankan oleh Morris et al. (1997), perhatian lebih besar dalam teori dan praktek harus ditekankan pada unsur manusia dan interaksi kompleks yang dinamis yang terungkap selama suksesi. Hal ini merupakan pendekatan suksesi dari perspektif baru: satu hal yang sensitif yaitu suksesi yang bersifat interaktif dan dinamis dan berfokus pada perilaku suksesi daripada memperlakukannya sebagai sebuah prestasi yang harus direncanakan dan dinilai berdasarkan hasil.

Westhead dan Cowling (1998), menunjukkan bahwa dalam suatu bisnis keluarga terdapat dimensi sebagai berikut : kepemilikan saham, partisipasi anggota keluarga dalam tim manajemen atau ruang rapat, dan manajemen transgenerasional atau 
transisi kepemilikan dalam keluarga. Kegagalan dalam proses suksesi tidak hanya menimbulkan masalah kehancuran kesejahteraan ekonomi keluarga, tetapi juga menyebabkan "ternodanya" nama keluarga sebagai bisnis keluarga yang sering dipandang sebagai identitas keluarga (Dyer \& Whetten, 2006; Arosa, Iturralde \& Maseda, 2010). Oleh karena itu, kegagalan proses suksesi seringkali menjadi "mimpi buruk" bagi pemilik bisnis keluarga, terutama generasi pendahulu karena memandang peristiwa itu bukan saja merupakan kegagalannya dalam mengelola usaha saja, tetapi lebih sebagai bentuk kegagalannya dalam memimpin keluarga.

Kemampuan menjalankan usaha bisa saja diperoleh generasi penerus melalui proses pendidikan formal ataupun informal, tetapi kemauan untuk menjalankan usaha adalah tergantung kepada mindset kepemilikan yang utamanya dibentuk dari lingkungan keluarga, utamanya pengalaman sejak dini yang diperoleh penerus dengan terlibat langsung dalam bisnis keluarga. Apabila generasi sebelumnya tidak pernah atau terlambat memikirkan perencanaan suksesi maka sangat mungkin terjadi kegagalan atas keberlanjutan bisnis keluarga (Dunn \& Holtyz-Eakin, 2000; Hayton, George \& Zahra, 2002).

Beberapa persoalan utama yang menyebabkan kegagalan proses suksesi adalah perebutan kekuasaan di antara para calon generasi penerus, munculnya sikap ketidakpuasan pasca proses suksesi dari para anggota keluarga yang tidak terpilih sebagai penerus usaha keluarga, ataupun saat pihak pendiri/pemilik saat ini atau pihak penerus potensial yang seharusnya menggantikan kepemimpinan bisnis keluarga tibatiba meninggal (Molly, Laveren \& Deloof, 2010; Lussier \& Sonfield, 2010).

Sejumlah fakta menunjukkan bahwa walaupun proses suksesi merupakan satu tahapan penting bagi keberlanjutan bisnis keluarga, ternyata banyak bisnis keluarga yang cenderung mengabaikan hal itu. Dengan demikian, proses suksesi seharusnya merupakan tahapan yang direncanakan secara baik untuk mewujudkan keberlanjutan bisnis keluarga. Keberhasilan atau kegagalan proses suksesi dalam sebuah bisnis keluarga dapat dipengaruhi oleh dua aktor utama, yaitu generasi pendahulu (predecessor) dan generasi penerus (successor). Stewardship theory berdalil bila kedua pihak tersebut lebih mengedepankan perilaku altruism, atau mementingkan kepentingan ataupun kesejahteraan para anggota keluarga keluarganya, di dalam nilai-nilai usaha yang dikandung, maka besar kemungkinan terjadi keberhasilan dalam proses suksesi yang mendukung bisnis keluarga dalam mempertahankan keberlanjutan usahanya maupun mencapai pertumbuhan yang diharapkan, dan berikutnya mampu menciptakan kesejahteraan lebih besar bagi keluarga. Namun bila sikap itu tidak dimiliki oleh salah satu atau kedua aktor utama tersebut maka bisa terjadi kegagalan di dalam proses suksesi yang menyebabkan penurunan performa perusahaan dan menurunkan tingkat kesejahteraan keluarga (Lam, 2011; CabreraSuarez, Saa-Perez \& Garcia-Almeida, 2001).

Keberhasilan proses suksesi oleh kedua aktor utama juga dipengaruhi oleh faktor lingkungan 
(environmental factors), yang seharusnya memiliki fungsi sebagai fasilitator ataupun aktor pendukung (supporter). Faktor lingkungan dinilai memiliki peran penting lebih besar saat bisnis keluarga yang menjalani proses suksesi berkategori skala usaha kecil, khususnya keterkaitan dalam aspek sosial dibandingkan aspek ekonomi (Kuratko, 1993; Lucky, Minai \& Isaiah, 2011).

Villalonga dan Amit (2006) yang menganalisis 508 perusahaan yang terdaftar dalam Fortune 500 selama periode 1994-2000, menemukan bahwa para investor lebih menyukai bisnis keluarga yang masih dijalankan oleh generasi pendahulu. He, Wang, Mei, Lian (2010) pada hasil analisis studinya atas 307 perusahaan yang tercatat di database milik China Center for Economic Research untuk periode 2001 sampai 2005, menyimpulkan bahwa mundurnya generasi pendahulu akan berdampak negatif terhadap performa bisnis keluarga. Argumen yang diberikan adalah karena generasi pendahulu dinilai bersikap lebih proaktif dalam menjalin hubungan dengan para stakeholder, dan lebih berani mengambil resiko dalam memanfaatkan peluang-peluang yang menguntungkan bagi bisnis keluarga; sementara generasi penerus lebih bersikap defensif serta kurang atau tidak mau mengambil resiko yang dipandangnya bisa membahayakan kesejahteraan yang dinikmati oleh keluarganya saat ini, walaupun peluang yang ada tersebut sangat menguntungkan bagi perusahaan. Juga, karena generasi pendahulu telah memiliki hubungan baik dengan stakeholder dan telah terbukti pola pengelolaan yang dilakukannya.Sebaliknya, generasi penerus adalah orang baru di dalam aktivitas operasional bisnis keluarga, yang diragukan kemampuannya dalam memimpin bisnis keluarga (Daily \& Thompson, 1994).

Namun demikian, sifat dominasi atas perannya di dalam bisnis keluarga, secara sadar ataupun tidak sadar, dapat menyebabkan generasi pendahulu terjebak dalam situasi yang disebut "founder trap" (Kodrat, 2008; Kaye \& Hamilton, 2004; Aronoff, 1998). Founder trap adalah kondisi yang terjadi karena generasi pendahulu bersikap tidak mempercayai kemampuan siapapun, baik generasi penerus ataupun pihak professional eksternal, dalam mengelola bisnis keluarga. Konsekuensinya, saat generasi pendahulu tersebut meninggal, maka terjadi "kekosongan kekuasaan" yang signifikan atas bisnis keluarga dan bisa terjadi persaingan di antara para anggota keluarga ataupun dengan pihak eksternal untuk memperebutkan posisi kekuasaan yang "kosong" itu. Kondisi itu secara khusus biasanya terjadi pada bisnis keluarga yang berskala kecil dan menengah, dimana umumnya tidak memiliki perencanaan secara formal dan sistematik dalam mengelola proses suksesi. Permasalahan ini umumnya tersingkap saat generasi pendahulu menjadi semakin tua dan tidak berdaya, dan proses suksesi menjadi satu-satunya pilihan bagi keberlanjutan bisnis keluarga (Wulandari, 2009).

Situasi rumit lainnya dengan adanya dominasi tersebut adalah kondisi "generational shadow" ataupun "legacy centrality", yaitu bentuk intervensi yang berlebihan oleh generasi pendahulu atas generasi penerus. Situasi tersebut bisa terjadi karena generasi pendahulu bersikap 
"setengah hati" dalam mengalihkan kekuasan atas bisnis keluarga sehingga masih seringkali melakukan intervensi ataupun merupakan bentuk pemantauan secara berlebihan atas setiap kebijakan yang diambil oleh penerus (Davis \& Harveston, 1999; Kelly, Athanassiou \& Crittenden, 2000; Athanassiou et al., 2002). Kondisi ini menjadikan bisnis keluarga menjadi sulit berubah atau untuk melakukan transformasi, dimana para penerus dianggap tabu untuk melakukan suatu perubahan atas warisan generasi pendahulu, baik berupa strategi, sistem, budaya maupun gaya kepemimpinan.

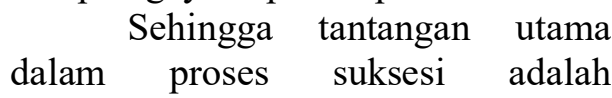
keterlibatan dua pihak utama, yaitu generasi pendahulu dan generasi penerus. Disadari bahwa kedua pihak tersebut memiliki era hidup, situasi pendidikan dan pengalaman, serta orientasi masa datang yang berbeda, sehingga bisa memunculkan perilaku berbeda di sepanjang proses tersebut. Dengan demikian, perlu penyelarasan pemikiran dan tindakan antara kedua pelaku utama tersebut agar proses suksesi yang dilaksanakan menghasilkan efek positif bagi pencapaian keberlangsungan usaha yang lebih baik bagi bisnis keluarga. Agar proses suksesi berjalan mulus, generasi pendahulu diharapkan menciptakan hubungan komunikasi yang hamonis baik dengan generasi penerus maupun para anggota keluarga yang lain. Keterbukaan di dalam bisnis keluarga, misalnya komunikasi tentang pengambilan keputusan strategis perusahaan, dapat mendukung kerjasama di antara ketiganya (Chrisman, Chua \& Sharma, 1998).

Walau demikian, Handler (1990) mengingatkan bahwa motivasi dari generasi pendahulu dalam pelaksanaan proses suksesi dapat mempengaruhi perilaku generasi penerus dan kelancaran proses suksesi. Generasi pendahulu hendaknya memiliki keinginan untuk "berbagi mimpi" (share a dream) tentang membangun bisnis keluarga yang tumbuh berkembang di masa datang dengan anggota keluarga, terutama penerus yang telah ia pilih untuk menerima tanggungjawab melanjutkan bisnis keluarga. Keinginan pendahulu untuk mentransfer kekuasaan kepada generasi berikutnya dapat membantu bisnis keluarga menyadari dan mengeksploitasi peluang-peluang baru yang diekspektasikan dapat memberi keuntungan ataupun manfaat jangka panjang bagi keberlangsungan hidup perusahaan (Block, 2010; Lansberg, 1988).

\section{Suksesi pada Bisnis Keluarga di Indonesia}

Studi yang dilakukan Soedibyo (2007) pada 80 bisnis keluarga di Indonesia menunjukkan bahwa keberhasilan bisnis keluarga dalam mencapai tujuan jangka panjang sangat dipengaruhi oleh proses transisi kepemimpinan, yaitu transfer aspek kepemimpinan dari generasi pendahulu ke generasi berikutnya yang disebut "Pemetaan Suksesi/Mapping Succession". Mengalihan pimpinan puncak (CEO) yang direncanakan dengan baik akan menjamin keberlanjutan filosofi bisnis, nilai-nilai dan identitas perusahaan dari keluarga untuk generasi mendatang. Sehingga isu suksesi ini sangat mempengaruhi keberhasilan dan kesinambungan bisnis keluarga.

Menurut Fekum (2011), hasil penelitian The Consulting Group 
Jakarta (JCG) mengungkapkan bahwa sejumlah bisnis keluarga terkemuka di Indonesia tengah memasuki masa transisi kepemimpinan. Survey JCG dilakukan terhadap 87 bisnis keluarga berskala menengah ke atas yang tersebar di berbagai kota di Indonesia, hasilnya juga menjelaskan bahwa $34 \%$ bisnis keluarga pada dekade ini akan melakukan suksesi kepada generasi kedua. Berlangsungnya masa transisi kepemimpinan itu tidak lepas dari sejarah berdirinya bisnis keluarga tersebut. Perusahaan yang akan melakukan suksesi umumnya adalah bisnis keluarga yang didirikan pada kurun waktu 1956-1967 (10\%) dan 1968-1979 (24\%). Pertimbangannya, usia pendiri ketika itu diasumsikan berada pada kisaran 30-35 tahun. Ketika perusahaan-perusaan itu masih bertahan hingga kini, maka artinya gerak roda perusahaan telah melewati masa 3-5 dasawarsa. Sehingga bila dilihat dari siklus perusahaan, siklus umur, dan historisnya, perusahaan keluarga tersebut dalam 10 tahun ke depan akan melakukan suksesi.

Tirdasari dan Dewanto (2012) menyatakan bahwa mayoritas perusahaan di Indonesia didominasi oleh bisnis keluarga yang tersebar di berbagai bidang di Indonesia, bisnis keluarga seringkali dikaitkan dengan isu-isu tentang suksesi yang menghasilkan perencanaan suksesi dalam bisnis keluarga. Suksesi merupakan atribut penting yang diharapkan dapat mengantisipasi terjadinya konflik internal dan disorganisasi dalam bisnis keluarga.

\section{Budaya Organisasi (Corporate Culture)}

Culture didefinisikan oleh Hofstede (1991) sebagai program mental yang berpola pikiran (thinking), perasaan (feeling), dan tindakan (action) atau disebut dengan "software of the mind". Dan merupakan suatu sistem nilai yang dianut oleh suatu lingkungan, baik lingkungan keluarga, lingkungan sekolah, lingkungan kerja, sampai pada lingkungan masyarakat luas. Pemrograman mental atau budaya ini dikembangkan melalui suatu sistem nilai yang berkembang dalam masyarakat, kemudian sistem nilai ini akan menjadi norma-norma sosial yang mempengaruhi perilaku sosial.

Pada studi lainnya, Hofstede (1980) mengungkapkan bahwa konsep budaya dari program mental dapat dibedakan ke dalam tiga tingkatan, yaitu: (1). Tingkat universal, yaitu program mental yang dimiliki oleh seluruh manusia sehingga seluruhnya melekat pada diri manusia. (2). Tingkat collective, yaitu program mental yang dimiliki hanya oleh beberapa orang, pada tingkatan ini terdapat program mental khusus yang dilakukan pada kelompok atau kategori dan dapat dipelajari. (3). Tingkat individual, yaitu program mental yang unik yang dimiliki oleh hanya seorang atau dua orang dan tidak akan memiliki program mental yang persis sama. Pada tingkatan ini program mental sebagian kecil melekat pada diri manusia, dan lainnya dapat dipelajari dari masyarakat, organisasi atau kelompok lain. Hofstede menurunkan budaya dari tingkatan yang kedua (collective) sehingga budaya adalah sesuatu yang dapat dipelajari bukan merupakan suatu gen tetapi diturunkan dari lingkungan sosial, organisasi ataupun kelompok lain. Budaya ini dibedakan antara sifat manusia dan dari kepribadian individu. 


\begin{abstract}
Menurut Susanto et al. (2008)
budaya perusahaan (corporate

culture) dapat berpengaruh signifikan

bagi kinerja perusahaan. Perusahaan dengan budaya yang menaruh perhatian kepada stakeholdernya seperti pemegang saham, pelanggan, dan supplier-nya, serta memiliki jiwa kepemimpinan yang kuat dan efektif akan berkinerja lebih baik dibandingkan dengan perusahaan yang kurang menaruh perhatian atau tidak memiliki jiwa kepemimpinan yang kuat dan efektif. Budaya perusahaan juga merupakan faktor yang penting dalam menentukan keberhasilan ataupun kegagalan perusahaan. Akan tetapi budaya juga dapat menjadi penghalang perusahaan dalam mengadaptasi strategi atau perubahan taktik yang dibutuhkan.

Hofstede (1991) juga telah mengkategorikan lapisan budaya untuk mengelompokkan kebiasaan orang sesuai dengan lingkungannya:
\end{abstract} (a). Tingkatan nasional (national level), berdasarkan suatu negara. (b). Tingkatan daerah (regional), dan/atau suku (ethnic), dan atau agama (religion), dan atau bahasa (linguistic). (c). Tingkatan perbedaan jenis kelamin (gender). (d). Tingkatan generasi, misalnya orang tua dengan anak-anak. (e). Tingkatan sosial, dihubungkan dengan pendidikan, dan pekerjaan atau profesi. (f). Tingkatan organisasi atau perusahaan. Selain itu Hofstede (1991) juga menemukan bahwa manager dan karyawan memiliki lima dimensi nilai kultur nasional yang berbeda-beda. Kelima kultur tersebut adalah: (1). Jarak kekuasaan/Power Distance, merupakan sifat kultur nasional yang mendeskripsikan tingkatan dimana masyarakat menerima kekuatan dalam institusi dan organisasi yang didistribusikan secara tidak sama. (2).
Individualisme/Kolektivisme.

Individualisme merupakan sifat kultur nasional yang mendeskripsikan tingkatan dimana orang lebih suka bertindak sebagai individu daripada sebagai kelompok. Kolektivisme menunjukkan sifat kultur nasional yang mendeskripsikan kerangka sosial yang kuat dimana individu mengharapkan orang lain dalam kelompok mereka dapat menjaga dan melindunginya. (3). MaskulinitasFeminimitas. Merupakan tingkatan dimana kultur lebih menyukai peranperan maskulin tradisional seperti pencapaian, kekuatan, dan pengendalian versus kultur yang memandang pria dan wanita memiliki posisi sejajar. Penilaian maskulinitas yang tinggi menunjukkan bahwa terdapat peran yang terpisah untuk pria dan wanita, dengan pria yang mendominasi masyarakat. (4). Penghindaran ketidakpastian merupakan tingkatan dimana individu dalam suatu negara lebih memilih situasi terstruktur dibandingkan tidak terstruktur. (5). Orientasi jangka panjang merupakan tipologi terbaru dari Hofstede. Poin ini berfokus pada tingkatan ketaatan jangka panjang masyarakat terhadap nilai-nilai tradisional. Individu dalam kultur orientasi jangka panjang melihat ke masa depan dan menghargai penghematan, ketekunan dan tradisi.

Cohen (1974) menjelaskan bahwa latar belakang etnis (culture) dari komisaris utama suatu perusahaan dapat direpresentasikan dengan adanya loyalitas dari suatu kelompok etnik yang terdiri dari kumpulan orang-orang yang mempunyai pola tingkah laku normatif. Sedangkan menurut Susanto et al. (2008), dalam budaya organisasi terdapat enam sumber utama yang sangat 
mempengaruhinya, yaitu: (1). Budaya masyarakat atau budaya nasional di mana organisasi berada secara fisik. (2). Visi, gaya manajerial, dan kepribadian para pendiri organisasi atau pemimpin yang dominan. (3). macam bisnis yang digeluti dan nature of business environment. (4). Struktur organisasi. Struktur organisasi misalnya struktur birokratis akan melahirkan pula budaya yang cenderung birokratis. (5). Pelanggan. Perilaku pelanggan akan berpengaruh terhadap perilaku organisasi. (6). Tradisi warisan organisasi yang tercermin dalam nilai maupun artefak. Berbagai sumber budaya organisasi ini menjadikan budaya setiap organisasi sangat bersifat spesifik dan unik.Dari ancangan ini, maka budaya organisasi bersifat relatif dan tidak ada budaya yang baik atau buruk, tetapi yang ada adalah budaya itu sesuai atau tidak untuk diterapkan.

Susanto et al. (2008) juga menyatakan bahwa budaya yang berkembang dalam sebuah perusahaan keluarga yang sukses, dapat terlihat dimana anggota keluarga memainkan perannya dengan baik, dan merasa mempunyai makna. Dan juga bila di dalam perusahaan telah terjadi internalisasi mengenai Family Governance, hidup dalam semangat kewirausahaan yang tinggi dan diimbangi dengan manajemen risiko, serta berorientasi pada operasional perusahaan yang unggul.

\section{Budaya Organisasi dalam Bisnis Keluarga Tionghoa}

Semakin

berkembang

pesatnya dunia bisnis yang dilakukan oleh masyarakat etnis Tionghoa sangat mengagumkan banyak pihak. Di negara China sendiri, banyak perusahaan besar yang harus memperbaiki pengelolaan dalam bisnisnya, hal ini karena para pengusaha di negara China tersebut dengan terus terang telah menantang para pesaing bisnis dari negara lain yang mencoba meraih keuntungan dari konsumen yang semula dimilikinya di berbagai sektor industri dan perdagangan. Hingga saat ini dunia bisnis di berbagai belahan negara termasuk di area Macan Asia (Taiwan, Hongkong, dan Singapura) masih tetap dalam kekuasaan para pengusaha beretnis Tionghoa. Perusahaan kecil dan menengah telah mempekerjaan lebih dari 50\% tenaga kerja di negara-negara Asia, dan etnis Tionghoa menguasai kepemilikan $90 \%$ dari perusahaan-perusahaan tersebut (Tjoe, 2008).

Negara Indonesia yang berBhinneka Tunggal Ika dikenal memiliki keberagaman budaya. Salah satunya dengan adanya etnis Tionghoa yang merupakan warga keturunan negara China yang seringkali dianggap sebagai kaum minoritas di Indonesia, dan ternyata memberikan pengaruh yang sangat kuat dalam dunia bisnis (Kusumastuti, Supatmi, \& Sastra, 2007)

Sebelum era reformasi, etnis keturunan Tionghoa seringkali memperoleh perlakuan diskriminasi oleh masyarakat pribumi Indonesia.Akan tetapi sekarang, keberadaan etnis ini bahkan diakui telah memberikan kontribusi yang besar dalam mengembangkan perekonomian bangsa ini. Belum ada teori khusus yang cukup sahih dan bisa menunjukkan dengan pasti apa yang membuat etnis Tionghoa bisa menjadi sangat mahir dan sukses dalam berbisnis (Sugiyono, 2007). 
Budaya tradisional masyarakat Tionghoa dalam berbisnis banyak dipengaruhi oleh nilai-nilai Konfusianisme. Tujuan ideal Konfusianisme adalah menjadi seorang yang berbudi mulia dengan berpegang teguh pada prinsip moralitas dan tidak sedikitpun meninggalkan perbuatan baik, bahkan tidak akan berbuat sekedar untuk mencari sesuap nasi. Asumsi ini bisa menjadi salah satu rahasia keberhasilan usaha etnis Tionghoa.Orang-orang keturunan Tionghoa juga meyakini bahwa untuk berhasil dalam bisnis seringkali harus lebih dahulu melakukan pengorbanan dan investasi.Orang Tionghoa sejak nenek moyangnya turun-temurun hingga sekarang adalah sebagai penganut sistem nilai yang bermuara pada ajaran Konfusius (Tjoe, 2008).

Menurut Chinomona (2012) dalam studinya, ada tiga hal yang dapat dirujuk sebagai kunci sukses bisnis masyarakat etnis China: (1). Guanxi (jaringan bisnis); (2).Ganqing, menghormati dan menjaga ikatan perasaan/hubungan batin yang dalam; serta (3).Xinyong, jaringan antar-pribadi, berkaitan dengan reputasi.Guanxi dapat diartikan sebagai relasi (relationships). Dalam dunia bisnis China, Guanxi juga diartikan sebagai jaringan di antara berbagai pihak yang bekerja sama dan mendukung satu sama lain. Hal ini sangat berpengaruh besar terhadap kesuksesan bisnis.Dengan menerapkan Guanxi secara benar, sebuah perusahaan dapat meminimalkan resiko dan meminimalkan ketidaknyamanan ketika melakukan bisnis.

Dalam budaya bisnis China, konsep ganqing berhubungan dekat dengan guanxi.Ganqing merefleksikan suasana umum dari hubungan sosial dari dua orang atau dua badan yang saling berinteraksi. Seseorang dapat dikatakan memiliki ganqing yang baik jika hubungannya dengan orang lain tersebut baik, selain track-record hubungan yang baik di antara keduanya. Sedangkan ganqing yang mendalam adalah terdapatnya ikatan perasaan yang dalam pada hubungan sosial itu sendiri.Orang China berusaha sebisa mungkin menghindari suatu konflik dalam melanggengkan hubungan dengan sesamanya. Ketika mereka menghindari konflik biasanya orang China akan berusaha untuk tidak menyebabkan seseorang kehilangan mianzi-nya, yaitu dengan tidak memunculkan kenyataan-kenyataan yang memalukan ke hadapan publik. Xinyong dalam budaya bisnis China bermakna sebagai sebuah jaringan antar pribadi.Bagi orang China kepercayaan antar pribadi merupakan hal yang terpenting.Para pengusaha China biasanya hanya berhubungan komersial dengan orang yang sudah mereka kenal.Oleh karena itu, reputasi seseorang penting artinya bagi transaksi bisnis. Dahulu, para pebisnis China secara pribadi akan berhubungan langsung dengan rekanrekan bisnisnya, karena hal ini akan meningkatkan kemutlakan peran pemilik di samping tetap menjaga reputasinya sebagai pemilik perusahaan (Langenberg, 2007).

\section{Suksesi pada Bisnis Keluarga Beretnis Tionghoa di Indonesia}

Sebagian orang berpendapat bahwa kesuksesan bisnis keluarga beretnis Tionghoa didorong adanya etos kerja tinggi, yang merupakan ciri khas semangat kaum minoritas tersebut.Sikap hemat dan disiplin merupakan inti dari filosofi bisnis, 
yang juga menjadi ciri khas kehidupan bisnis warga beretnis Tionghoa.Sebagai etnis minoritas, warga keturunan Tionghoa memiliki kebudayaan yang terus dijunjung tinggi, hal inilah yang memungkinkan mereka dapat bertahan dan berhasil dalam menjalankan bisnisnya.Jika terdapat pengaruh antara keberadaan etnis Tionghoa dengan nilai perusahaan hal itu karena sebagian besar perusahaan yang memiliki anggota dewan beretnis Tionghoa, merupakan bisnis keluarga, di mana anggota dewan adalah anggota keluarga sendiri.Jadi, perusahaan merekrut orang-orang yang masih merupakan saudara dengan alasan supaya perusahaan tetap berada di bawah kekuasaan keluarganya sendiri (Sugiyono, 2007).

Survei yang dilakukan oleh Permatasari dan Mustamu (2015) tentang perencanaan suksesi pada perusahaan keluarga beretnis Tionghoa menunjukkan bahwa proses suksesi didasarkan pada beberapa yaitu: aspek penentuan nilai dasar, pengembangan suksesor, seleksi, dan transisi. Dimana dalam menentukan nilai dasar dilakukan melalui beberapa tahapan, yaitu :

1. Kriteria seleksi bagi suksesor yang meliputi: memiliki jiwa leadership, berwawasan luas, inovatif dan mempunyai passion dalam melanjutkan dan mengembangkan perusahaan.

2. Suksesor yang diinginkan harus berasal dari dalam anggota keluarga, karena anggota keluarga yang bergabung cenderung mengerti nilai-nilai keluarga yang dibangun di dalam perusahaan.

3. Identifikasi potensi bagi suksesor dilakukan oleh subjek penelitian dengan melakukan uji kemampuan bagi suksesornya, berupa tes psikologi dan tes kelayakan.

4. Komposisi kepemilikan saham dari anggota keluarga yang bergabung terdiri dari $50 \%$ direktur utama, 25\% anak pertama, $15 \%$ anak kedua, dan $10 \%$ publik. Pembagian dilakukan atas dasar tradisi keluarga Tionghoa di mana anak tertua mendapat bagian lebih banyak daripada anak bungsu.

Permatasari dan Mustamu (2015) juga menyatakan bahwa pengembangan suksesor dilakukan dalam beberapa tahapan, yaitu:a). Program pendidikan formal yang efektif bagi suksesornya demi terciptanya potensial yang baik. b). Program meliputi training kerja dalam jangka waktu tertentu yang bertujuan untuk mengasah skill suksesor dan memilah kelebihan dan kekurangan yang dimiliki calon suksesor dalam bidang tertentu. c). Menetapkan standar pengalaman kerja bagi suksesor agar dapat mengembangkan pengetahuan dasar, membentuk identitas, kepercayaan diri, serta kredibilitas. d). Pengalaman di luar bisnis merupakan salah satu rekomendasi kuat dalam membangun penerus. Selain itu dalam menetapkan suksesor dari generasi pendahulu juga dilakukan proses seleksi dan tahap transisi dimana pada tahapan ini incumbent (generasi pendahulu) mulai menarik diri secara perlahan namun tidak melepas secara keseluruhan sehingga masih terus dilakukan pemantauan hingga suksesor dianggap mampu melakukan perannya sendiri.

\section{METODOLOGI PENELITIAN}

Metode penelitian yang digunakan peneliti dalam rangka untuk memperoleh dan menganalisis 
data adalah metode penelitian kualitatif dalam kerangka paradigma interpretatif. Jenis penelitian yang digunakan sesuai dengan karakteristik lapangan ini merupakan jenis penelitian etnografi. Penelitian ini bertujuan untuk memperoleh pemahaman dan menafsirkan makna praktek suksesi perusahaan keluarga etnis Tionghoa terkait dengan tata kelola dan budaya organisasi dalam rangka melanggengkan perusahaan mereka.

Makna tersebut dinilai terefleksi di dalam berbagai pemikiran ataupun tindakan yang dimunculkan oleh pihak-pihak yang terlibat dalam proses suksesi, dan merupakan realitas dari fenomena sosial yang hanya dapat dipahami berdasarkan penuturan langsung oleh pelaku terkait dengan proses tersebut. Untuk memahami makna-makna di dalam konteks dari suatu fenomena maka digunakan paradigma interpretif (interpretive) yang bersifat terbuka kepada teori namun tidak terikat kepada teori yang bersangkutan, sehingga bisa mengembangkan teori itu berdasarkan fakta-fakta yang tereksplorasi di lapangan (Myers, 2009).

Teori-teori yang ada lebih bersifat membantu peneliti untuk memahami makna dan intensi dari para aktor yang diteliti. Paradigma itu juga berguna untuk memahami kompleksitas pemikiran manusia atas suatu situasi yang muncul karena memungkinkan terjadi perbedaanperbedaan interpretasi atas suatu hal yang sama (Eriksson \& Kovalainen, 2011).

Penerapan paradigma
interpretif bisa membantu
pemahaman atas pengalaman-
pengalaman personal dan sosial yang
mendasari bentuk-bentuk motivasi

maupun tindakan dari para pelaku utama dalam proses suksesi. Melalui paradigma interpretif akan terpahami sifat unik (uniqueness) suatu perusahaan keluarga di dalam suatu konteks lingkungan secara lebih baik, yang mana dinilai sulit untuk dipahami jika hal tersebut dikuantifikasikan (Short, Payne, Brigham, Lumpkin, \& Broberg, 2009).

Ditengarai masih adanya gap informasi cukup besar mengenai pengelolaan perusahaan keluarga, apalagi "rahasia" turun-temurun mengenai proses suksesi dipandang sangat jarang tersebar kecuali jika kita bertanya langsung kepada para pelaku utamanya. Dengan demikian, melalui paradigma interpretif, penelitian ini berupaya menjembatani gap antara "apa yang kita ketahui (what we know)" dan "apa yang seharusnya kita ketahui (what we ought to know)" berkenaan dengan proses suksesi dalam perusahaan keluarga, khususnya yang terjadi di dalam situs penelitian.

Penelitian ini mendasarkan diri pada upaya penggalian data atau informasi atas berbagai realitas tindakan yang ditunjukkan oleh masing-masing individu pelaku, baik berupa perbuatan/perilaku atau perkataan dari subyek penelitian, ataupun pembicaraan di antara para subyek.Berbagai tindakan itu kemudian diinterpretasikan untuk mengungkap makna yang ada dibalik tindakan yang difenomenakan, yang disebut noumena.Makna subyekif itulah yang dinyatakan membentuk realitas tindakan yang ditampakkan atau digejalakan oleh masing-masing individu pelaku (Strauss \& Corbin, 2009).

Upaya penggalian makna
subyektif itu mendorong desain




\begin{abstract}
penelitian ini menggunakan pendekatan fenomenologi. Apabila dikaitkan kepada konteks penelitian ini, paham fenomenologi menyatakan bahwa makna proses suksesi hanya bisa dipahami bila ditanyakan dan digali ke dalam pemahaman atau interpretasi aktor utama yang berpengalaman langsung dengan proses tersebut. Pemahaman atau interpretasi itu akan terkait kepada mind atau pattern of thinking serta self dari aktor yang bersangkutan dalam merefleksikannya melalui berbagai tindakan di sepanjang proses suksesi. Hasil interaksi dengan berbagai situasi dan kondisi sosial, ekonomi maupun budaya lingkungan sehari-harinya, akan melatarbelakangi dan membentuk motif tindakan dirinya.
\end{abstract}

\section{Teknik Pengumpulan Data}

Data utama yang digunakan dalam studi ini dikumpulkan melalui teknik wawancara mendalam. Wawancara dilakukan dengan etnis bisnis keluarga Tionghoa langsung dan berkomunikasi tatap muka dengan informan kunci. Dalam desain metode fenomenologi, wawancara lebih disarankan untuk dilakukan secara informal, interaktif yang terangkai dalam alur dialog yang bebas, mendalam dan terbuka.Wawancara tatap-muka tersebut juga berguna untuk mengamati mimik muka dan gerak tubuh dari informan kunci.
Menurut Moleong (2011), dalam proses wawancara, dapat dilakukan pendalaman (probing) agar dapat lebih mengeksplorasi tematema yang menarik dari isu penelitian serta untuk menjaga kemungkinan terjadinya bias. Juga dimungkinkan melakukan pendalaman yang bersifat saling mempertentangkan (antagonistic probes) yang dilakukan untuk mengkonfirmasi apakah mungkin terjadi pertentangan atau ketidakkonsistenan antara jawaban yang diberikan oleh generasi pendahulu dan generasi penerus atau antara generasi penerus yang satu dengan generasi penerus yang lain di dalam satu perusahaan keluarga. Upaya probing maupun antagonistic probes tersebut dilakukan secara sadar dan dalam situasi relaks agar tercipta kenyamanan bagi informan.

\section{Situs Penelitian dan Penentuan Informan}

Studi ini dilakukan pada bisnis keluarga beretnis Tionghoa dan saat studi dilakukan, bisnis keluarga ini teridentifikasi sudah pernah atau sedang menjalani proses suksesi. Titik utama penelitian ini adalah menggali makna dari tindakan para individu sebagai pelaku yang terlibat dalam fenomena proses suksesi. Mengingat keterbatasan waktu, maka hanya informan berikut yang digunakan oleh peneliti dengan situs penelitian di Kota Batam Kepulauan Ria 
Tabel 1.

Deskripsi Informan Kunci

\begin{tabular}{lll}
\hline No. & \multicolumn{1}{c}{ Generasi Pendahulu } & \multicolumn{1}{c}{ Generasi Penerus } \\
\hline 1. & IC $(53$ tahun $)$ & AC $(32$ tahun $)$ \\
2. & MT $(59$ tahun $)$ & RT $(37$ tahun $)$ \\
\hline Sumber : Data Diolah Peneliti (2018) &
\end{tabular}

\section{IMPLIKASI \& PEMBAHASAN HASIL STUDI}

Bertitik tolak dari hasil kajian literatur dan hasil-hasil survei sebelumnya, dilakukan eksplorasi singkat atas realitas untuk memperoleh pemahaman, penafsiran makna dan tindakan yang dilakukan oleh pihak-pihak yang terlibat dalam praktek suksesi terkait dengan tata kelola bisnis keluarga beretnis Tionghoa di Indonesia dalam rangka melanggengkan perusahaan mereka. Hal ini dilakukan melalui informasi yang diberikan oleh para informan yang terpilih.

Informasi yang diperoleh dari IC (usia 53 tahun), bahwa dalam tradisi budaya Tionghoa, anggota keluarga merupakan pemeran kunci dalam bisnis keluarga. Pada perusahaan keluarga yang dikelolanya telah dilakukan tata kelola atas perusahaan, yang dapat diketahui dengan adanya pembagian kepemilikan saham (ada prosentase kepemilikan), telah dibuatnya laporan keuangan bagi para pihak yang berkepentingan, dan telah diselenggarakannya audit baik untuk laporan keuangan maupun audit atas operasional perusahaan (dilakukan oleh audit internal maupun dengan bantuan pihak professional). Proses suksesi juga dilakukan secara transparan (diawali dari keluarga terdalam), melalui proses seleksi antar keturunan mereka dan ada tahapan transisi (generasi pendahulu tidak serta merta langsung melepaskan kepemimpinan, tetapi ada proses pemagangan bagi suksesor yang diterapkan sejak usianya masih dini). Meskipun demikian, bila generasi penerus dianggap kurang mampu (dalam hal pendidikan dan juga manajemen perusahaan) maka suksesor dapat dipilih dari luar keluarga inti (keponakan, menantu, saudara ipar).Hal ini dengan tujuan agar kelangsungan hidup usaha dapat semakin berkembang.

Menurut informasi AC (32 tahun) sebagai generasi penerus dari IC (53 tahun), perencanaan suksesi harus dilakukan sejak dini dengan melibatkan anggota keluarga.Dan sebaiknya ada pilihan bagi generasi penerus apakah ingin bergabung dengan perusahaan keluarga atau tidak. IC (53 tahun) menjelaskan juga bahwa pengalaman eksternal pada perusahaan lain juga diperlukan agar dapat memperkaya keterampilan dan pengalaman bagi bisnis keluarga. Biasanya calon suksesor yang terpilih awalnya diwajibkan bekerja pada perusahaan milik orang lain dengan harapan memperoleh tambahan pembelajaran secara praktik sebelum mengelola perusahaan keluarganya sendiri. Hal ini dengan tujuan untuk meningkatkan sifat kemandirian dari suksesor agar tidak ketergantungan dengan usaha yang diwarisi dari keluarganya.Perusahaan keluarga hendaknya selalu menciptakan pembelajaran dan pengembangan bagi generasi penerusnya.

Menurut informasi dari RT (37 tahun) sebagai penerus generasi MT (59 tahun), pelaku bisnis etnis 
Tionghoa menjalin jaringan bisnis dengan para pihak yang berkepentingan, tidak hanya untuk sekedar basa-basi, namun untuk menjalin suatu hubungan yang dilandasi oleh saling pengertian dan kesediaan untuk saling membantu. Memberikan bonus, diskon khusus dan hadiah kepada mitra bisnis menjadi hal yang lumrah dan biasa dilakukan di kalangan pelaku bisnis etnis Tionghoa.

Sedangkan informan MT (59
tahun) menginformasikan bahwa
Trilogi Guanxi, Ganqing, dan Xinyong dalam bisnis etnis Tionghoa selalu menjadi acuan penting dalam berbisnis dan menjalin hubungan dengan pihak yang berkepentingan (seperti pemasok, pengecer, bank, pejabat pemerintah daerah, dan stakeholder lainnya). Terkait proses suksesi pada bisnis keluarga beretnis Tionghoa, pada umumnya dilakukan dengan menerapkan budaya dan tradisi turun temurun dari nenek moyang mereka di negara China, yaitu lebih memprioritaskan anak tertua (terlebih anak laki-laki) yang didukung dengan kemampuan yang layak dalam berbisnis yang ditunjukkan oleh suksesor. Hal ini disebabkan karena dengan meningkatnya kebutuhan akan pengetahuan profesional di setiap bidang pekerjaan. Pendiri/generasi pendahulu harus segera memilih pengganti secepatnya apabila suksesor dari keluarga internal tidak ada, sehingga sebaiknya dicari alternatif lain, misalnya dengan mengangkat anggota keluarga eksternal (sepupu, menantu, dan sebagainya). Atau bisa juga dengan merekrut orang lain yang bukan merupakan anggota keluarga sebagai pengelola bisnis tersebut, dengan tetap memperhatikan persentase pembagian saham (kepemilikan saham terbesar tetap di tangan keluarga inti, agar usaha yang dirintis tidak jatuh ke tangan pihak luar).

\section{KESIMPULAN, KETERBATASAN, DAN SARAN}

Berdasarkan kajian literatur, hasil-hasil survei sebelumnya, dan wawancara singkat terhadap informan tersebut di atas, dapat disimpulkan bahwa sumber kekuatan pelaku bisnis keluarga etnis Tionghoa terletak pada perilakunya.Meskipun keberhasilan secara materi mulai mempengaruhi perilaku ekonomi, namun secara umum perilaku sosial masyarakat etnis Tionghoa masih mengacu pada kepercayaan ajaran Konfusionisme dan tata nilai budaya tradisional nenek moyang mereka di negara China.

Guna menghindari konflik keagenan dan untuk melanggengkan perusahaan yang telah dirintis oleh generasi pendahulu, pada beberapa perusahaan keluarga beretnis Tionghoa di Indonesia telah dilakukan tata kelola atas perusahaan, yang dapat diketahui dengan adanya pembagian kepemilikan saham (ada prosentase kepemilikan), penyusunan laporan keuangan, dan diselenggarakannya audit, kemudian dilakukannya proses suksesi yang transparan melalui proses seleksi dan tahap transisi. Semakin majunya sebuah perusahaan keluarga dapat ditunjukkan dengan semakin jelasnya aturan tentang kepemilikan, manajemen, dan tata kelola.

Banyak pebisnis keluarga beretnis Tionghoa yang menyadari bahwa pendelegasian kewenangan pengambilan keputusan harus mempertimbangkan pengetahuan, keterampilan dan kemampuan dari generasi penerusnya. Perencanaan 
suksesi yang jelas sangat diperlukan bagi kelangsungan hidup bisnis keluarga, sehingga dalam jangka panjang pertumbuhan perusahaan akan lebih terjamin.

Studi ini dilakukan dalam waktu yang singkat (kurang dari 1 tahun), sehingga keterbatasan dari studi interpretif ini adalah hanya menggunakan sedikit informan (dua keluarga pebisnis beretnis Tionghoa, yaitu generasi pendahulu dan penerusnya) yang dapat digali informasinya. Selain itu wawancara yang dilakukan masih kurang terstruktur karena baru menggunakan wawancara yang secara lisan. Meskipun kemungkinan informasi yang diperoleh belum cukup mendalam, diharapkan tetap dapat mewakili pengungkapan makna tata kelola perusahaan para pelaku bisnis etnis Tionghoa, termasuk bagaimana proses suksesi dan juga budaya yang diterapkan secara turun temurun dalam bisnis keluarga mereka.

Dari aspek bisnis, penggunaan trilogi Guanxi (jaringan bisnis), Ganqing (menghormati dan menjaga ikatan perasaan/hubungan batin yang dalam), serta Xinyong (jaringan antarpribadi, berkaitan dengan reputasi) merupakan kunci kesuksesan pengusaha etnis Tionghoa. Trilogi Guanxi, Ganqing, dan Xinyong dalam bisnis etnis Tionghoa merupakan suatu karakter hubungan antar manusia dalam dunia bisnis yang masih perlu digali lebih jauh apakah tepat untuk diterapkan di Indonesia dan diungkapkan pemaknaannya bila ditinjau dari sisi akuntansi, sehingga disarankan bahwa hal ini dapat menjadi peluang untuk dilakukannya riset lebih lanjut secara mendalam dan dalam waktu yang lebih panjang.

$\begin{array}{clr}\text { Forum } & \text { for } & \text { Corporate } \\ \text { Governance } & \text { (FCGI) } & \text { telah }\end{array}$

mengembangkan suatu alat untuk melakukan penilaian tata kelola perusahaan yang disebut FCGI Corporate Governance Self Assesment Checklist.Tetapi mengingat keterbatasan waktu studi, sehingga penggunaan penilaian tersebut belum diterapkan pada studi ini. Sehingga disarankan pula pada studi berikutnya dapat mengadopsi sistem penilaian FGCI untuk menilai apakah perusahaan-perusahaan keluarga etnis Tionghoa telah menerapkan seluruh prinsip-prinsip GCG.

\section{DAFTAR PUSTAKA}

Amran, N. A., \& Ahmad, A. C. (2010).Family succession and firm performance among Malaysian companies.International Journal of Business and Social Science, 1 (2), 193-203.

Anderson, R. C., \& Reeb, D. M. (2003). Founding-family ownership and business performance: Evidence for the $\mathrm{S} \& \mathrm{P}$ 500. The Journal of Finance, 58 (3), 1301-1328.

Aronoff, C. E. (1998).Megatrends in family business.Family Business Review, 11 (3), 181185.

Arosa, B., Iturralde, T., \& Maseda, A. (2010). Ownership structure and firm performance in nonlisted firms: Evidence from Spain. Journal of Family Business Strategy, 1 (2), 8896.

Athanassiou, N., Crittenden, W. F., Kelly, L. M., \& Marquez, P. (2002).Founder centrality effects on the Mexican family firm's top management group: Firm culture, strategic vision and goals, and firm 
performance.Journal of World Business, 37 (2), 139-150.

Block, J. H. (2010). R \& D investments in family and founder firms: An agency perspective. Journal of Business Venturing, 27 (2), 248-265.

Cabrera-Suarez, K., Da Saa-Perez, P., \& Garcia-Almeida, D. (2001). The succession process from a resource and knowledge based view of the family firm. Family Business Review, 14 (1), 37-47

Carter, D. A., Simkins, B. J., Simpson, W. G. (2003). Corporate governance, board diversity, and firm value.The Financial Review, 38 , 33-53

Chrisman, J. J., Chua, J. H., \& Sharma, P. (1998). Important attributes of successor in family businesses: An exploratory research. Family Business Review, 11 (1), 1934.

Chinomona, R. (2012). The influence of dealers' referent power and legitimate power in Guanxi distribution networks: The case of Taiwan's SME firms. African Journal of Business Management, 6 (37), 1012510137

Claessens, S., Djankov, S., \& Lang, L. H. P. (2000). The separation of ownership and control in East Asian corporation. Journal of Financial \& Economics, 58 (112), 81-112.

Clarke, T., \& Branson, D. (2012). Corporate governance. Sage Publications.

Cohen, A. (1974). Two-dimensional man, an essay on the anthropology of power and symbolism in complex society. USA: University of California Press.

Daily, C.,\& Thompson, S. (1994). Ownership structure, strategic posture, and firm growth: An empirical examination.Family Business Review, 7 (3), 237249.

Darmadi, S. (2012).Board structure in publicly-listed familycontrolled firms: mitigating or exacerbating agency issues?. Retrived from http://ssrn.com/abstract $=2147$ 217

Davis, J. H., Schoorman, F. D., \& Donaldson, L. (1997). Towards a stewardship theory of management.Academy of Management Review, 22, 2047.

Deegan, C. (2004). Financial accounting theory. McGrawHill. Australia: Pty Ltd, NSW.

Donaldson, L., \& Davis, J. H. (1991). Stewardship theory or agency theory: CEO governance and shareholder returns. Australian Journal of Management, 16, 49-64.

Dunn, T., \& Holtyz-Eakin, D. (2000). Financial capital, human capital, and the transition to self-employment: Evidence from intergenerational links. Journal of Labor Economics, 18 (2), 282-305.

Dyer Jr., W. G., \& Whetten, D. A. (2006). Family firms and social responsibility: preliminary evidence from the S\&P 500. Entrepreneurship Theory and Practice, 30 (6), 785-802.

Dyer Jr., W. G. (2010). Are you the right type of family business? 
Organizational Dynamics, 39 (3), 269-278.

Eddleston, K. A., \& Kellermans, F. W. (2007). Destructive and productive family relationships: A stewardship theory perspective. Journal of Business Venturing, 22 (4), 545-565.

Effendy, M. A. (2009).The power of good corporate governance.Teori dan implementasi. Jakarta: Salemba Empat.

Eisenhardt, K. M. (1989). Agency theory: An assessment and review. Academy of Management Review, 14, 5774.

Eriksson, P., \& Kovalainen, A. (2011). Qualitative methods in business research. London: SAGE Publications Ltd.

Fama, E., \& Jensen, M. (1983). Separation of ownership and control.Journal of Law and Economics, 26 (2), 301-325.

Fekum (2011, 19 April). Pintu aman masa depan perusahaan keluarga. Warta Ekonomi, XXIII.

Gomper, P., Ishii, J., \& Metrick, A. (2003). The corporate governance and equity prices.The Quaterly Journal of Economics, 118 (1), 107-155.

Handler, W. C. (1990). Succession in family firms: A mutual role adjustment between entrepreneur and nextgeneration family members. Entrepreneurship Theory \& Practice, 15 (1), 37-51.

Haque, F., Arun, T., \& Kirkpatrick, C. (2011). The political economy of corporate governance in developing economies: The case of
Bangladesh. Research in International Business and Finance, 25(2), 169-182.

Harveston, P. D., Davis, P. S., \& Lyden, J. A. (1997). Succession planning in family business: The impact of owner gender. Family Business Review, 10 (4), 373-396.

Hayton, J. C., George, G. \& Zahra, S. A. (2002). National culture and entrepreneurship: A review of behavioral research. Entrepreneurship Theory and Practice, 26 (4), 33-52.

He, X., Wang, Z., Mei, L., \& Lian, Y. (2010). The impact of founder turnover on firm performance: An empirical study in China. Journal of Chinese Entrepreneurship, 2 (2), 148164.

Hofstede, G. (1980). Culture's consequences: international differences in work-related values. Beverly Hills CA: Sage Publications.

Hofstede, G (1991). Cultures and organizations: software of the mind. New York: McGrawHill USA.

Hsu, R. (2008). China fireworks. Hoboken, New Jersey: John Wiley \& Son.

Jensen, M. C., \& Meckling, W. H. (1976). Theory of the business: Managerial behavior, agency costs and ownership structure. Journal of Financial Economics, 13, 305-360.

Kaye, K., \& Hamilton, S. (2004). Roles of trust in consulting to financial families.Family Business Review, 17 (2), 151163.

Kelly, L. M., Athanassiou, N., \& Crittenden, W. F. (2000). 
Founder centrality and strategic behavior in the family-owned firm. Entrepreneurship Theory andPractice, 25 (2), 27-42.

Kodrat, D. S. (2008).Siklus hidup perusahaan keluarga di Indonesia (Studi pada PT. Nyonya Meneer).Usahawan, 06 (37), 27-35.

Kuratko, D. (1993). Family business succession in Korean and U.S. firms. Journal ofSmall Business Management, 31 (2),132-136.

Kusumastuti, S., Supatmi., \& Sastra, P. (2007). Pengaruh board diversity terhadap nilai perusahaan dalam perspektif corporate governance.Jurnal Akuntansi dan Keuangan, 9 (2), 88-98.

La Porta, R., Lopez-de-Silanes, F., \& Shleifer, A (1999). Corporate governance around the world.Journal of Finance, 54 (2), 471-517.

Lam, W. (2011). Dancing to two tunes: Multi-entity roles in the family business succession process. International Small Business Journal, 29 (5), 508533.

Langenberg, E. A. (2007) Guanxi and Business Strategy : Theory and implications for multinational companies in China. Heidelberg New York : Physica-Verlag.

Lansberg, I. (1988). The succession conspiracy.Family Business Review, 1 (2), 119-143.

Lansberg, I. (1999). Succeeding generations: realizing the dream of families in business. Boston, USA: Harvard Business School Press.
Lucky, E. O., Minai, M. S., \& Isaiah, A. O. (2011). A conceptual framework of family business succession: Bane of family business continuity. International Journal of Business and Social Science, 2 (18), 106-113.

Lussier, R. N., \& Sonfield, M. C. (2010).A six-country study of first, second, and third generation family business.International Journal of Entrepreneurial Behaviour \& Research, 16 (3), 414-436.

McConaughy, D., Walker, M., Henderson, G., \& Mishra, C. (1998). Founding family controlled firms: Efficiency and value. Review of Financial Economics, 7 (1), 119.

Moleong, L. J. (2011). Metodologi penelitian kualitatif. Edisi Revisi. Bandung: Remaja Rosdakarya.

Molly, V., Laveren, E., \& Deloof, M. (2010). Family business succession and its impact on financial structure and performance.Family Business Review, 23 (2), 131-147.

Morck, R., \& Yeung, B. (2004), Family control and the rentseeking society.Entrepreneurship Theory and Practice, 28 (4), 391-409.

Morris, M. H., Williams, R. W., \& Nel, D. (1996). Factors influencing family business succession.International Journal of Enterpreneurial Behaviour and Research, 2 (3), 68-81.

Myers, M. D. (2009). Qualitative research in business \& 
management. London: SAGE Publications Ltd.

Permatasari, L., \& Mustamu., R. H (2015). Analisis proses suksesi pada perusahaan manufaktur farmasi. AGORA, 3 (2), 542-546.

Pounder, P. (2015). Family business insights: an overview of the literature. Journal of Family Business Management, 5 (1), $116-127$

Sato, Y. (2003). Corporate governance in Indonesia: A study on governance of business groups. Asian Development Experiment, 2, 88-136.

Short, J. C., Payne, G. T., Brigham, K. H., Lumpkin, G. T. \& Broberg, J. C. (2009). Family firms and entrepreneurial orientation in publicly traded firms: A comparative analysis of the S \& P 500. Family Business Review, 22 (1), 9-24.

Siagian, F. T. (2011). Ownership structure and governance implementation: Evidence from Indonesia. International Journal of Business, Humanities and Technology, 1 (3), 187.

Soedibyo, M. (2007, 9 September). Penerus perusahaan keluarga kadang tidak berlangsung lama.Suara Pembaruan, p. 2.

Strauss, A. \& Corbin, J. (2009). Dasar-dasar penelitian kualitatif. Yogyakarta: Pustaka Pelajar.

Sugiyono. (2007). Menjawab stigma, mewariskan tradisi. Retrived June, 14, 2007, from http://www.kabarejogja.com/

Susanto, A. B., Sujanto., Wijanarko., Himawan., Patricia., Mertosono., ...\& Ismangil, W.
(2008). A strategic

management approach,

corporate culture \& organization culture. From http://swa.co.id/tag/thejakarta-consulting-group/

Susanto, A. B. (2009). Suksesi dalam family business; 70\% gagal sampai generasi kedua. Retrived April, 17, 2009, from https://ifambiz.wordpress.com

Susanto, A. B., \& Susanto, P. (2013). The dragon network: inside stories of the most successful chinese family business. Singapore: John Wiley \& Sons.

Suyono, E. (2015). Reaksi investor terhadap pemilihan auditor spesialis industri pada perusahaan keluarga di Bursa Efek Indonesia. Jurnal Keuangan dan Perbankan, 19 (1), 1-15.

Tirdasari, N. L., \& Dhewanto, W. (2012). Family business succession in Indonesia: A study ofhospitality industry. Procedia - Social and Behavioral Sciences, 57, 6974.

Tjoe, T. L. (2008).Rahasiasuksesbisnisetn isTionghoa di Indonesia. Media Pressindo. Yogyakarta.

Villalonga, B., \& Amit, R. (2006). How do family ownership, control and management affect firm value?.Journal of Financial Economics, 80, 385-417.

Ward, J. L. (1997). Growing the family business: Special challenges and best practices. Family Business Review, Family Firm Institute, 10 (4), 
323-337.

Westhead, P. \& Cowling, M. (1998). Family firm research: the need for a methodological rethink. Entrepreneurship Theory and Practice, 23 (1), 31-56.

Wheelen, T. L. and Hunger, J. D (2012). Strategic management and business policy. (13th ed). Pearson Prentice Hall.

Wulandari, I. S. (2009). Suksesi, nasib perusahaan keluarga di tangan generasi ketiga. Retrived 2009, 5, Februari, from

https://iswekon.wordpress.co $\mathrm{m} /$ author/. 